\title{
RAGAM BENTUK DAN DESAIN SARANA PENJAHIT KELILING DI WILAYAH PERUMAHAN BINTARO JAYA SEKTOR 1 DAN 2 JAKARTA SELATAN
}

\author{
Awang Eka Novia Rizali \\ Program Studi Desain Produk Universitas Trisakti Jakarta \\ E-Mail: awangenr@gmail.com
}

\begin{abstract}
The national economic changes have effect the life of urban communities. The difficulties of meeting the needs of daily living drive a person to find a way to increase their income. Mobile tailor is a service to make and to repair the clothes, known also as "tukang permak Levis". Mobile tailors can be seen in Jakarta and suburban and approaching the customers in residence area. The means of mobile tailor is a modification of bicycle that has simple designed by the user. This research focus on the form and design varieties of mobile tailors in Bintaro Jaya Sektor 1 and 2 residence area, South Jakarta. The method is qualitative $m$ e thod with design approach. The interviewees of this research are tailors who have various form and design of mobile tailors in the research area. The data collecting method is observation and interview with the interviewees. The result of this research is the description of mobile tailor's form and design that has changing as the changing of the needs and condition of the user, and user convortability in doing the activities.
\end{abstract}

Keywords: form, design, mobile, tailors, means

\section{ABSTRAK}

Perubahan kondisi ekonomi nasional mempengaruhi kehidupan masyarakat di perkotaan dan daerah-daerah sekelilingnya. Sulitnya memenuhi kebutuhan hidup seharihari membuat masyarakat mencari jalan untuk menambah penghasilan. Penjahit keliling merupakan usahajasa menjahit dan memperbaiki pakaian, yang disebut juga sebagai tukang permak Levis. Penjahit keliling banyak ditemui di Jakarta dan sekitarnya, bekerja mendatangi pelanggan di daerahdaerah perumahan. Sarana penjahit keliling yang digunakan merupakan modifikasi dari sepeda yang dirancang secara sederhana. Penelitian ini berfokus pada keragaman bentuk dan desain sarana penjahit keliling di wilayah perumahan Bintaro Jaya Sektor 1 dan 2, Jakarta Selatan. Metode penelitian yang digunakan adalah kualitatif dengan pendekatan keilmuan desain. Narasumber pada penelitian ini adalah para penjahit keliling yang memiliki bentuk desain sarana penjahit keliling yang berbeda-beda di daerah penelitian. Data didapat melalui observasi di daerah penelitian dan wawancara dengan narasumber. Hasil dari penelitian ini adalah jabaran keragaman bentuk dan desain sarana penjahit keliling yang disesuaikan dengan kondisi, situasi, dan kebutuhan pengguna, serta kenyamanan pengguna dalam melakukan aktivitasnya.

Kata kunci: bentuk, desain, sarana, penjahit, keliling

\section{Pendahuluan}

Perubahan kondisi ekonomi nasional sebagai akibat dari perubahan kondisi ekonomi dunia menyebabkan terjadinya 
berbagai masalah dan fenomena perkotaan saat ini, antara lain banyaknya perusahaanperusahaan konveksi di Indonesia yang $\mathrm{t}$ erpaksa melepaskan tenaga-tenaga penjahitnya akibat kesulitan ekonomi dan kekurangan modal. Penjahit keliling atau tukang permakLevis, merupakan profesi jasa yang terdapat di daerah Jakarta dan sekitarnya sebagai akibat hilangnya pekerjaan sebagai penjahit di perusahaan konveksi tersebut. Levis, sebenarnya merek produk jeans terkenal, namun orang awam cenderung menggunakan kata Levis untuk menyebut jeans. Adanya kebutuhan untuk permak jeans dan memperbaiki pakaian dari bahan lain ini menyebabkan terbukanya peluang profesi penjahit keliling di wilayah urban.

Saat ini banyak bermunculan penjahit keliling di kawasan Perumahan Bintaro Jaya, selain di wilayah lain kota Jakarta dan sekitarnya. Penjahit keliling menyediakan jasa menjahit dan memperbaiki pakaian dengan mendatangi pelanggan di daerahdaerah perumahan. Sarana penjahit keliling yang digunakan memiliki keragaman bentuk dan desain yang dibuat dari modifikasi bentuk sepeda sesuai dengan keinginan dan kebutuhan penggunanya. Keragaman bentuk dan desain sarana penjahit keliling ini dipengaruhi oleh situasi dan kondisi pengguna dan lingkungan sekitarnya.

Dari latar belakang dan permasalahan di atas maka pertanyaan penelitian ini adalah bagaimana ragam bentuk dan desain sarana penjahit keliling yang dibuat untuk memenuhi kebutuhan penjahit keliling sebagai pengguna? Untuk itu penelitian ini berfokus pada perkembangan ragam bentuk dan desain sarana penjahit keliling di wilayah perumahan Bintaro Jaya 1 dan 2 sebagai wilayah penelitian. Tujuannya untuk memahami ragam bentuk dan desain yang digunakan sesuai dengan aktivitas pengguna sebagai penjahit keliling. Sehingga pada akhirnya akan bermanfaat untuk keilmuan desain produk pada khususnya dan perkembangan desain di Indonesia pada umumnya.

\section{Kajian Pustaka}

Berkembangnya kota dan tingkat $\mathrm{k}$ e padatan penduduk y ang tinggi menyebabkan lahan pekerjaan menjadi amat terbatas. Akibatnya banyak masyarakat yang berusaha menciptakan lapangan kerja sendiri dengan modal terbatas. Menjamurnya usaha ini secara luas tanpa aturan-aturan yang mengikat, kemudian dikenal sebagai sektor informal. Lingkupnya hampir tak terbatas, mulai pedagang kaki lima, penjaja asongan, penjual jasa keliling, hingga pemulung. Secara perorangan mungkin mereka tidak membutuhkan desain, tetapi dilihat dari skala makro dan ketertiban perkotaan, tentu usaha mereka perlu penanganan partisipatif dari dirinya sendiri dan pihak-pihak terkait. Untuk itu pemecahan desain tetap diperlukan sebagai salah satu alternatif dengan memperhatikan konsep perkotaan (Sachari, 2007: 86).

Penelitian sebelumnya yang dilakukan oleh Mochamad Burhan Islami, dari Jurusan Desain Produk Industri, Fakultas Teknik Sipil dan Perencanaan, ITS, pada tulisan ilmiah berjudul "Desain Rombong Penjual Makanan Kaki Lima Sistem Semi Prasmanan", mengemukakan hasil analisis dari beberapa jenis analisis, yaitu: (a) Analisis aktivitas, untuk mengetahui aktivitas apa saja yang dilakukan oleh penjual dan pembeli, (b) Studi aspek teknis, yang meliputi studi struktur, studi sistem, dan mekanisme rombong, untuk mengetahui fungsi teknis yang akan diterapkan, termasuk studi dan analisis material masing-masing komponen rombong, (c) Pengkajian estetika, yang membahas 
elemen estetis yang diterapkan pada rombong, meliputi studi bentuk dan warna.

Hasil dari analisis aktivitas, adalah rangkaian aktivitas utama dan konsep awal rombong yang berisi kebutuhan dan komponen yang diperlukan untuk memfasilitasi penjual dan pembeli. Rangkaian proses aktivitas meliputi 3 (tiga) tahap, yaitu Pra, Sedang, dan Pasca. Selanjutnya dianalisis sifat, konfigurasi, dan volume barang yang dibawa, untuk didapatkan kesimpulan kebutuhan dari analisis aktivitas penjual. Tahap lanjutan dari tahap analisis aktivitas adalah pengkajian studi aspek teknis, yang menghasilkan alternatif-alternatif desain yang bisa dijadikan perbandingan rancangan pada tahap akhir penelitian. Pengkajian tahap akhir adalah pengkajian estetika, meliputi studi bentuk dan warna disinkronisasikan dengan image semi prasmanan.

Hasil dari penelitian ini memaparkan bahwa konsep desain rombong penjual makanan kaki lima semi prasmanan adalah compact, preserve, fresh, interactive. Bentuk rombong yang kompak memiliki sistem operasional yang ringkas. Rombong memiliki fasilitas penyimpanan makanan dan display dengan sistem pemanas untuk menjaga kualitas makanan. Desain dengan fasilitas semi prasmanan memudahkan interaksi antara penjual dan pembeli (http://digilib.its.ac.id).

Sebuah desain selalu memiliki tujuan tertentu. Dalam arti umum, desain difungsikan sebagai sarana untuk mengubah suatu kondisi menjadi lebih baik dari kondisi sebelumnya, dari sebuah kesukaran menjadi kemudahan. Tujuan desain akan tercapai berdasarkan tujuan tertentu yang ditetapkan sebelumnya. Secara garis besar, sebuah desain dapat dikatakan memenuhi kriteria tercapainya tujuan apabila: (a) Desain memenuhi kriteria fungsi yang ditetapkan sehingga sebuah karya desain dapat berfungsi dengan baik, (b) Desain memenuhi kriteria produksi, apabila desain dapat dibuat sesuai dengan karakteristik produksi yang ditetapkan, (c) Desain memenuhi kriteria operasional, sesuai dengan karakteristik operasional yang dituntut oleh pengguna karya desain tersebut, (d) Desain dapat diperoleh oleh para pengguna, yang meliputi kriteria ekonomi dan kriteria kualitas visual, (e) Desain memenuhi nilai etik yang berlaku pada satu masyarakat tertentu, serta beberapa kriteria lain yang bergantung pada karakteristik objek yang dirancang (Masri, 2010:31-32).

Sarana penjahit keliling menggunakan sepeda sebagai komponen utamanya. Sepeda dipahami sebagai alat transportasi berbiaya kecil, ringan, membutuhkan perawatan yang minimum, dan bertahan lama. Sepeda juga dipandang tidak membutuhkan tempat parkir yang luas, ramah lingkungan, dan hemat energi. Dalam penggunaannya sebagai sarana penjahit keliling, ada kebutuhan desain untuk memberikan soluasi terhadap permasalahan keamanan dan kenyamanan, dalam kaitannya dengan barang bawaan pengguna (Balaram, 2011:217).

Posisitubuh pengguna juga mempengaruhi kenyamanan tubuh dalam melakukan aktivitas. Posisi tubuh yang terbaik pada saat melakukan aktivitas menjahit adalah pada posisi netral, yang posisi di mana bagianbagian tubuh dalam kondisi rileks. Berat badan bertumpu pada bagian tengah tubuh. Ketinggian kursi dan posisi pengendali mesin jahit harus disesuaikan, sehingga lengan dan bahu dalam keadaan rileks. Posisi duduk yang benar dapat membuat dan mempertahankan sikap tubuh yang sempurna dan tersangga dengan baik sehingga tidak ada otot yang tegang dan nyeri. Kursi harus disesuaikan dengan cara duduk operator pada mesin 
dengan kaki tepat di atas pedal. Kursi yang dis e suaikan dengan benar akan menghilangkan tekanan dari bagian depan kursi pada bagian bawah pinggang. Sandaran kursi harus berada pada posisi vertikal untuk menyangga punggung dan tinggi kursi juga disesuaikan sehingga menyangga tulang belakang bagian pinggang dengan baik. Selain itu posisi tubuh yang baik dalam melakukan aktivitas bersepeda sangat penting. Posisi tubuh tegak tidak disarankan karena menimbulkan tekanan pada bagianbagian tubuh.

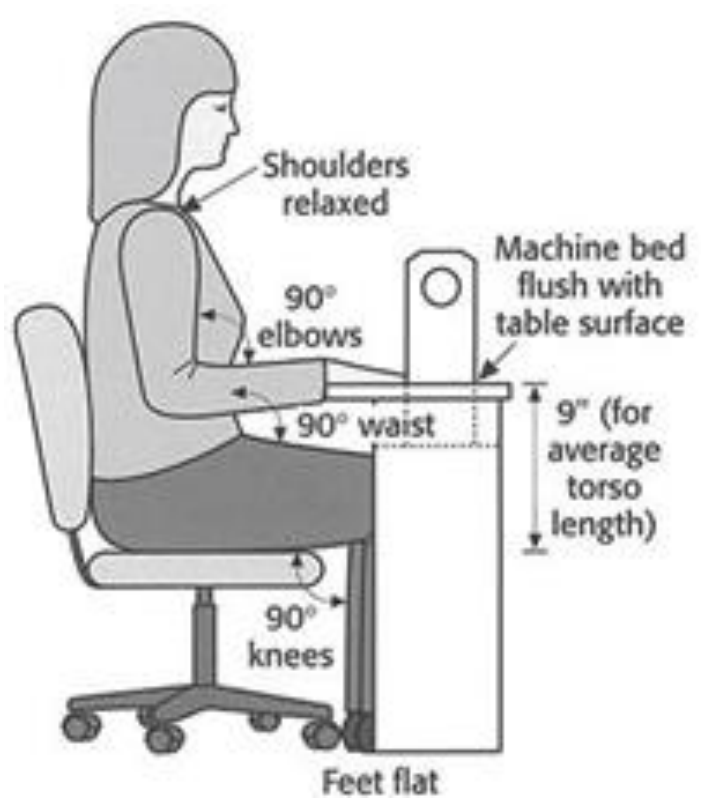

Gambar 1. Ergonomi Mesin Jahit Sumber : http://blog.shopmartingale.com/

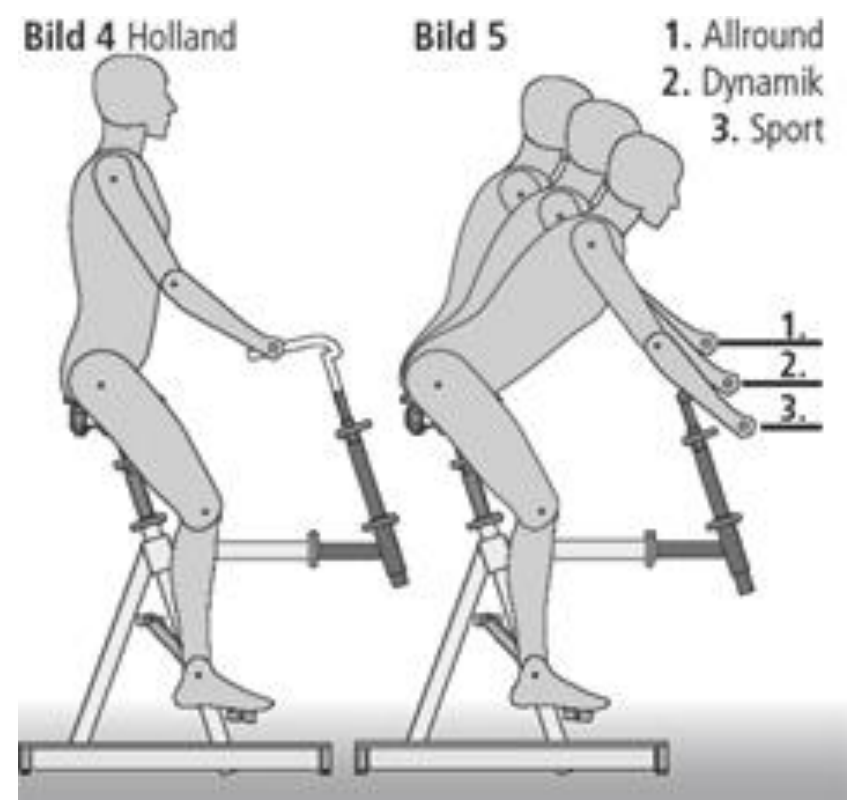

Gambar 2. Posisi Tubuh Saat Mengayuh Sepeda Sumber : http://www.patria.net/en/ergonomics/dutch-bicycle-sitting-position/ 
Posisi tubuh tegak adalah (A) posisi tubuh untuk mengendarai city bike. Dalam posisi tangan seperti ini, tubuh bagian belakang dituntut tetap aktif untuk menjaga keseimbangan tubuh bagian atas. Tulang belakang dalam posisi natural ( $S$-shape) yang merupakan posisi paling baik untuk menyerap goncangan. Sadel dan seatpost yang berguna sebagai peredam goncangan yang sangat dibutuhkan untuk posisi tubuh saat mengayuh.

\section{Metode Penelitian}

Sebagai objek penelitian adalah sarana penjahit keliling yang banyak dapat ditemui di area perumahan di Jakarta dan sekitarnya untuk menjajakan jasa dari rumah ke rumah dari pagi hingga sore hari. Pembatasan wilayah penelitian adalah di Perumahan Bintaro Jaya, Sektor 1 dan 2, Jakarta Selatan.Pembatasan wilayah survey dan penelitian dilakukan untuk memberikan fokus pada penelitian. beberapa penjahit keliling yang memanfaatkan waktu untuk beristirahat sambil tetap menjual jasanya di tempat tersebut.

Metode penelitian yang digunakan adalah deskriptif kualitatif, dengan pendekatan desain. Penelitian kualitatif menekankan pada nilai dan bertujuan untuk mendeskripsikan dan menerangkan serta menafsirkan berbagai fakta yang ada. Analisis dilakukan dalam beberapa tahap, yaitu: (a) Analisis aktivitas, untuk mengetahui aktivitas apa saja yang dilakukan oleh penjual dan pembeli, dan (b) Analisis bentuk dan desain sarana penjahit keliling sesuai kondisi dan kebutuhan aktivitas pengguna.

\section{Analisis Aktivitas Penjahit Keliling dan Pelanggan}

Analisis aktivitas bertujuan untuk mengetahui aktivitas apa saja yang dilakukan oleh pengguna, yaitu penjahit keliling, dan

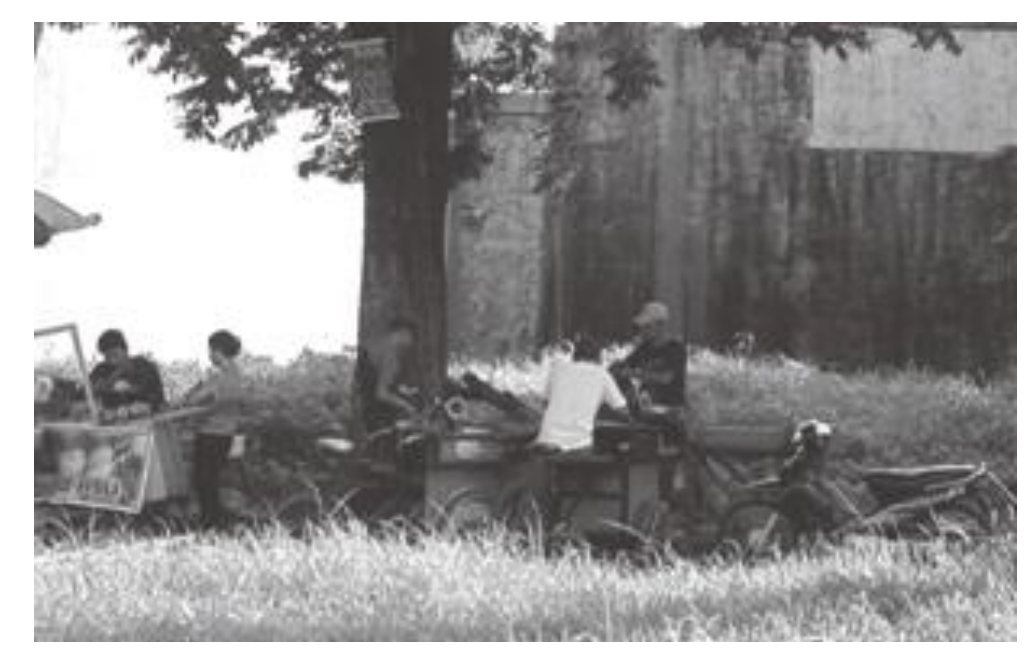

Gambar 3. Tempat Berkumpul Penjahit Keliling di Perumahan Bintaro Jaya, Sektor 1 Sumber: Awang E.N.R, Desember 2013

Di lokasi penelitian yang merupakan lokasi perumahan tersebut terdapat beberapa titik kumpul para pedagang keliling termasuk penjahit keliling. Di titik kumpul yang menjadi tempat mangkal ini dapat ditemui pelanggannya. Penjahit keliling merupakan pengguna atau pemakai produk secara langsung (direct user). Sebagai pengguna langsung, penjahit keliling menggunakan produk secara langsung dengan intensitas 
tinggi. Sedangkan pelanggan adalah pengguna tidak langsung (undirect user) yang menggunakan produk secara tidak langsung dan dengan intensitas rendah.

Dalam melakukan aktivitasnya, penjahit keliling memiliki kebebasan dalam mengatur waktu dan tempat beraktivitas. Pada umumnya penjahit keliling mencari penghasilan dengan berkeliling dari rumah ke rumah, sampai ada pelanggan yang membutuhkan. Atas permintaan pelanggan, penjahit keliling melakukan aktivitas di muka rumah ataupun tempat di mana penjahit keliling tersebut dihentikan. Seorang penjahit keliling memiliki wilayah di mana ia mencari penghasilan, sampai akhirnya memperoleh pelanggan di sekitar area tersebut. Wilayah kerja penjahit keliling menyebabkan jalan- jalan yang dilewati penjahit keliling pada saat mencari pelanggan menjadi relatif tetap. Hal ini menyebabkan calon pelanggan dapat menunggu datangnya penjahit keliling pada saat membutuhkan pada waktu-waktu tertentu. Penjahit keliling pada waktu-waktu tertentu seperti di tengah hari kemudian mencari tempat berteduh dan beristirahat, untuk setelah itu kembali berkeliling sampai waktu bekerjanya usai.

Selain itu ada pula penjahit keliling yang memilih tempat menetap (mangkal). Penjahit keliling seperti ini biasanya telah cukup lama berkeliling sampai akhirnya memiliki pelanggan tetap. Untuk itu pelanggan dapat menghubungi lewat telepon selular secara langsung ke penjahit keliling tersebut.

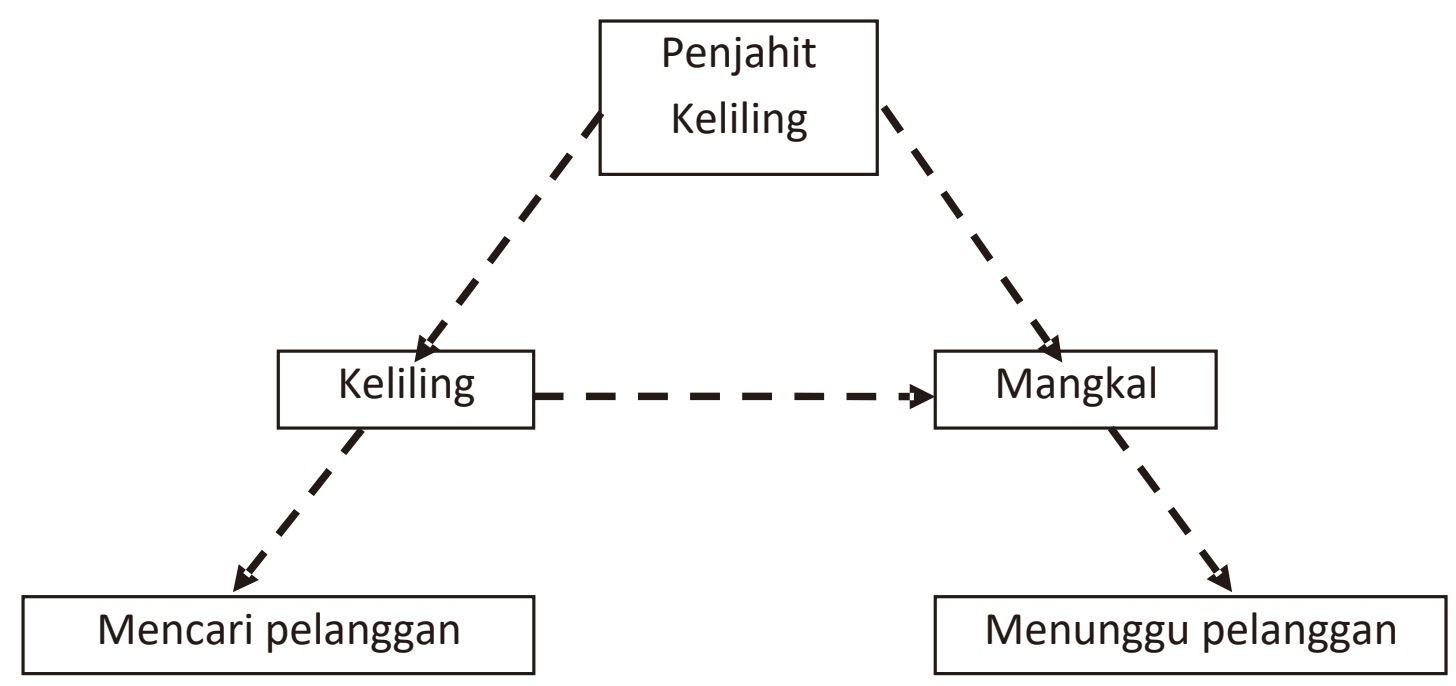

Gambar 4. Skema Aktivitas Penjahit Keliling 
Dengan adanya perbedaan cara penjahit keliling dalam memperoleh pelanggan, maka terdapat ragam aktivitas penjahit keliling dan pelanggan seperti dipaparkan pada tabel-tabel di bawah ini.

Tabel 1. Aktivitas Penjahit Keliling yang Berkeliling

\begin{tabular}{|l|l|}
\hline No & Jenis Aktivitas \\
\hline 1 & Persiapan dan pengemasan peralatan dan bahan \\
\hline 2 & Berkeliling mengayuh sarana mencari pelanggan \\
\hline 3 & Berhenti dan menyiapkan sarana menjahit di tempat pelanggan \\
\hline 4 & Aktivitas menjahit: \\
& - Mengecilkan pinggang \\
& - Potong/memendekkan celana \\
& - Menambal baju/celana \\
& - Mengang badge \\
& - Menjahit kancing \\
& - Mengecilkan baju/celana \\
& Membuat baju/celana \\
\hline 5 & Memberahkan hasil jahitan ke pelanggan dan mengemas peralatan dan bahan \\
\hline 6 & Berpindah tempat, berkeliling mengayuh sarana mencari pelanggan \\
\hline 7
\end{tabular}

Tabel 2. Aktivitas Pelanggan untuk Penjahit Keliling yang Berkeliling

\begin{tabular}{|l|l|}
\hline No & Jenis Aktivitas \\
\hline 1 & Menunggu datangnya penjahit keliling \\
\hline 2 & Memperlihatkan baju/celana dan kebutuhan jasa \\
\hline 3 & Menyerahkan baju/celana yang akan dijahit \\
\hline 4 & Menunggu aktivitas menjahit dilaksanakan: \\
& - Mengecilkan pinggang \\
& - Potong/memendekkan celana \\
& - Menambal baju/celana \\
& - Memasang badge \\
& $-\quad$ Menjahit kancing \\
& $-\quad$ Membuat baju/celana \\
\hline 5 & Menerima hasil jahitan dari penjahit keliling \\
\hline 6 & Membayar jasa penjahit keliling \\
\hline
\end{tabular}


Tabel 3. Aktivitas Penjahit Keliling yang Mangkal

\begin{tabular}{|l|l|}
\hline No & Jenis Aktivitas \\
\hline 1 & Persiapan dan pengemasan peralatan dan bahan \\
\hline 2 & Mengayuh sarana menuju tempat mangkal \\
\hline 3 & Berhenti dan menyiapkan sarana menjahit di tempat mangkal \\
\hline 4 & Menunggu pelanggan datang \\
\hline 5 & Aktivitas menjahit: \\
& $-\quad$ Mengecilkan pinggang \\
& $-\quad$ Potong/memendekkan celana \\
& $-\quad$ Menambal baju/celana \\
& $-\quad$ Mengganti retsleting \\
& $-\quad$ Mengecilkan baju/celana \\
& - Membuat baju/celana \\
\hline 6 & Menyerahkan hasil jahitan ke pelanggan \\
\hline 7 & Membereskan dan mengemas peralatan dan bahan \\
\hline 8 & Mengayuh sarana pulang \\
\hline
\end{tabular}

Tabel 4. Aktivitas Pelanggan untuk Penjahit Keliling yang Mangkal

\begin{tabular}{|c|c|}
\hline No & Jenis Aktivitas \\
\hline 1 & Menuju tempat penjahit keliling mangkal \\
\hline 2 & Memperlihatkan baju/celana dan kebutuhan jasa \\
\hline 3 & Menyerahkan baju/celana yang akan dijahit \\
\hline 4 & $\begin{array}{c}\text { Menunggu aktivitas menjahit dilaksanakan: } \\
-\quad \text { Mengecilkan pinggang } \\
-\quad \text { Potong/memendekkan celana } \\
-\quad \text { Menambal baju/celana } \\
-\quad \text { Memasang badge } \\
-\quad \text { Mengganti retsleting } \\
-\quad \text { Menjahit kancing } \\
-\quad \text { Mengecilkan baju/celana } \\
-\quad \text { Membuat baju/celana }\end{array}$ \\
\hline 5 & Menerima hasil jahitan dari penjahit keliling \\
\hline 6 & Membayar jasa penjahit keliling \\
\hline 7 & Meninggalkan tempat penjahit keliling mangkal \\
\hline
\end{tabular}

Dari pengamatan terhadap penjahit keliling yang ada di lokasi penelitian, terjadi perubahan aktivitas pencarian pelanggan. Penjahit keliling yang sebelumnya berkeliling mencari pelanggan, dengan adanya perkembangan teknologi seperti telepon selular dan adanya pelanggan tetap yang diperoleh di wilayah masing-masing penjahit keliling menyebabkan seorang penjahit keliling dapat menempati satu tempat untuk kemudian menunggu pelanggan datang. Meskipun ada perbedaan dalam cara 
mendapatkan pelanggan, pada dasarnya aktivitas utama adalah aktivitas menjahit. Aktivitas menjahit dilaksanakan secara beragam sesuai dengan permintaan pelanggan, dari memperbaiki/permak celana ataupun baju, memperbaiki bagian baju yang rusak seperti retsleting/kancing, sampai membuat baju/celana sesuai permintaan pelanggan. Aktivitas menjahit yang dapat ditunggu oleh pelangga n s e perti memperbaiki/permak celana, menggantiretsleting/kancing,memendekkan celana/rok, dilakukan di atas sarana penjahit keliling tersebut. Sedangkan aktivitas menjahit yang relatif besar seperti membuat baju/celana dilakukan penjahit keliling tersebut di rumah, bukan di atas sarana penjahit keliling pada saat mendatangi pel anggan. Hal tersebut dilakukan karena waktu yang dibutuhkan lebih lama dan perlunya ketelitian dan area kerja yang lebih memadai untuk membuat pola baju/celana sesuai dengan permintaan pelanggan.

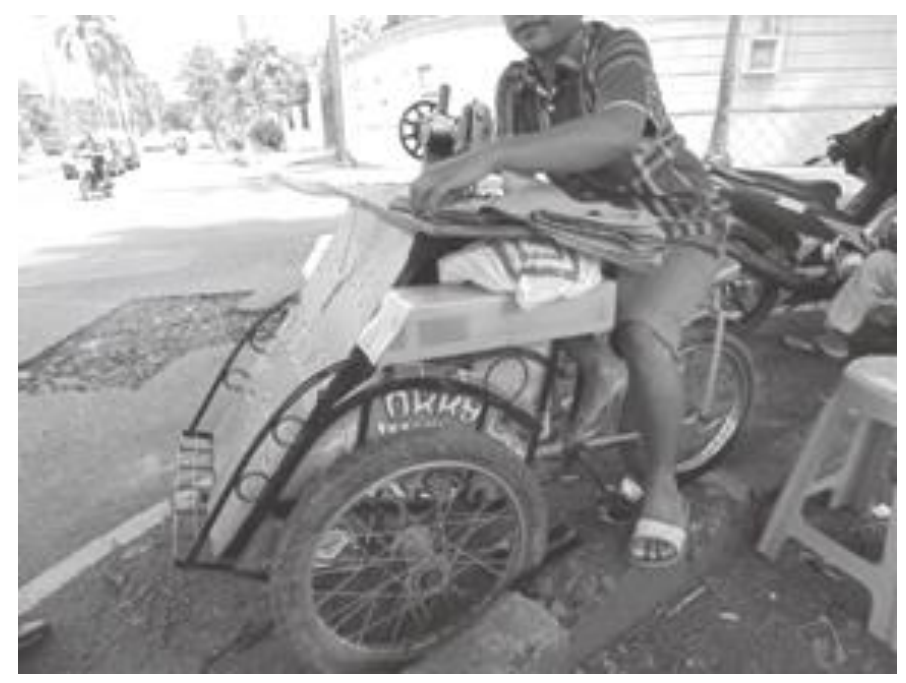

Gambar 5. Aktivitas Utama: Menjahit Sumber: Awang E.N.R, Maret 2014

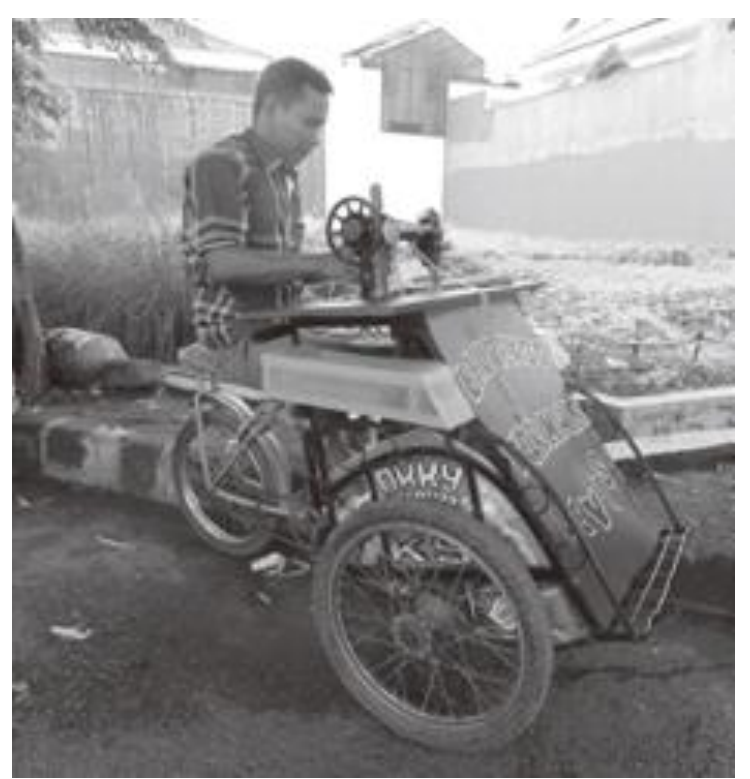

Gambar 6. Aktivitas Sekunder: Mempersiapkan Alat dan Bahan Sumber: Awang E.N.R, Maret 2014 
Sebagai aktivitas sekunder adalah kegiatan persiapan alat dan bahan pada sarana penjahit keliling, termasuk aktivitas mencari pelanggan. Sedangkan aktivitas tertier adalah kontak dengan pelanggan, seperti menerima dan mengembalikan baju/celana yang sudah dijahit, dan berkomunikasi serta menerima biaya jasa dari pelanggan. dalam menjalankan usaha jahit kelilingnya. Sepeda dipandang sebagai sarana transportasi yang berbiaya kecil, ringan, membutuhkan perawatan yang minimum, dan dapat bertahan lama. Selain itu sepeda juga ramah lingkungan dan hemat energi. Oleh sebab itu, desain sarana penjahit keliling dianggap berhasil

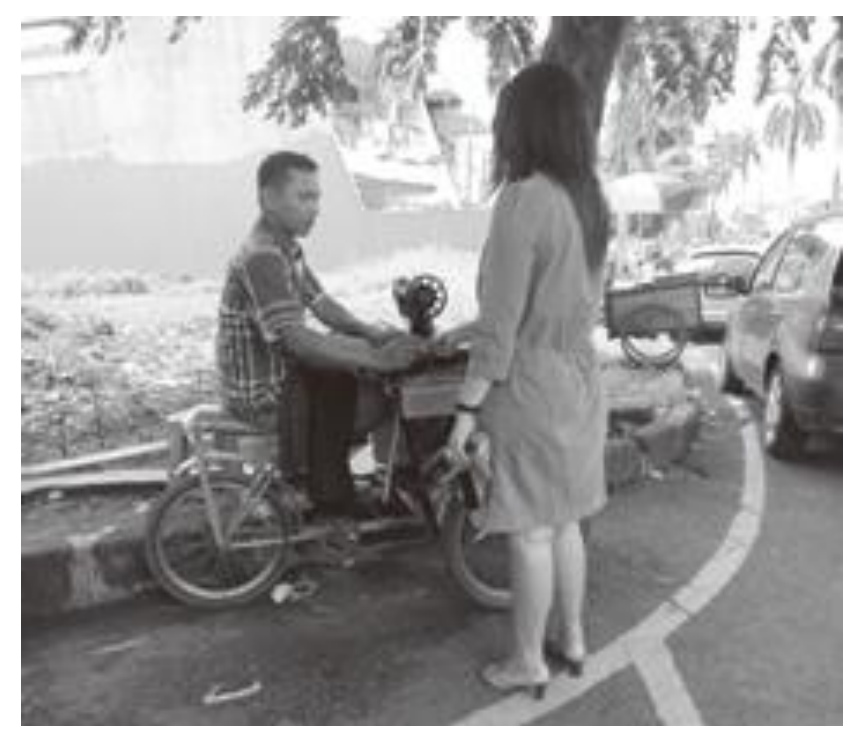

Gambar 7. Aktivitas Tertier: Interaksi dengan Pelanggan Sumber: Awang E.N.R, Maret 2014

Sehingga sebuah sarana penjahit keliling dibuat berdasarkan kebutuhan untuk pemenuhan aktivitas pengguna, terutama penjahit keliling dalam memberikan jasa kepada pelanggannya. Sebagai sarana yang mengedepankan mobilitas dalam fungsinya, seluruh aktivitas pengguna dilakukan di satu tempat, yaitu sarana penjahit kelilingnya.

\section{Analisis Bentuk dan Desain Sarana Penjahit Keliling}

Sebuah desain memiliki fungsi dan kegunaan yang disesuaikan dengan kebutuhan tertentu. Sarana penjahit keliling menggunakan sepeda sebagai komponen utamanya. Hal ini disesuaikan dengan kebutuhan sarana, yaitu digunakan untuk mempermudah mobilitas penjahit keliling apabila memenuhi kriteria fungsi, kriteria kegunaan, kriteria produksi, kriteria operasional, kriteria ekonomi, dan kriteria kualitas visual.

Sarana penjahit keliling dibuat dengan modal bervariasi sesuai dengan bentuk model yang diinginkan dan dibutuhkan oleh pengguna. Modal yang dibutuhkan juga beragam sesuai dengan material dan bentuk dasar sarana penjahit keliling yang digunakan untuk dimodifikasi demi memenuhi kebutuhan pengguna

Berdasarkan pengamatan di wilayah penelitian terdapat beberapa variasi ragam bentuk dan desain sarana penjahit keliling. Model 1 menggunakan bentuk sepeda utuh dari sepeda ontel dengan penambahan kotak untuk sarana menjahit pada bagian 
sampingnya. Dari wawancara diketahui modal yang dibutuhkan untuk membeli sepeda ontel adalah Rp 300.000,- dan untuk membuat bagian kotak mesin jahitsebesar Rp 300.000 ,- sehingga total modal yang dibutuhkan untuk modifikasi pembuatan sarana penjahit keliling ini sebesar $\mathrm{Rp}$ $600.000,-$. Tapi kendalanya adalah mencari sepeda ontel yang saat ini semakin sulit didapat, karena saat ini sepeda ontel semakin dicari sebagai benda koleksi dan gaya hidup dengan berkembangnya komunitas ontel di kota-kota besar sehingga harganya jadi mahal. Pada sarana penjahit keliling Model 1 seperti ditunjukkan pada gambar di atas ini, bentuk sepeda tetap utuh, sehingga posisi tubuh pada saat mengayuh adalah dalam posisi normal mengayuh sepeda.

Posisi handle menyebabkan tubuh tidak terlalu tegak sebagaimana pada model-model sebelumnya, dan pengendalian gerak sarana penjahit keliling yang relatif lebih mudah. Posisi tubuh pada aktivitas menjahit juga mendekati posisi normal, di mana jarak antara tubuh pengguna dengan meja dan mesin jahit cukup ideal dan posisi kedua kaki dalam keadaan sejajar berada di dalam kotak meja mesin jahit.

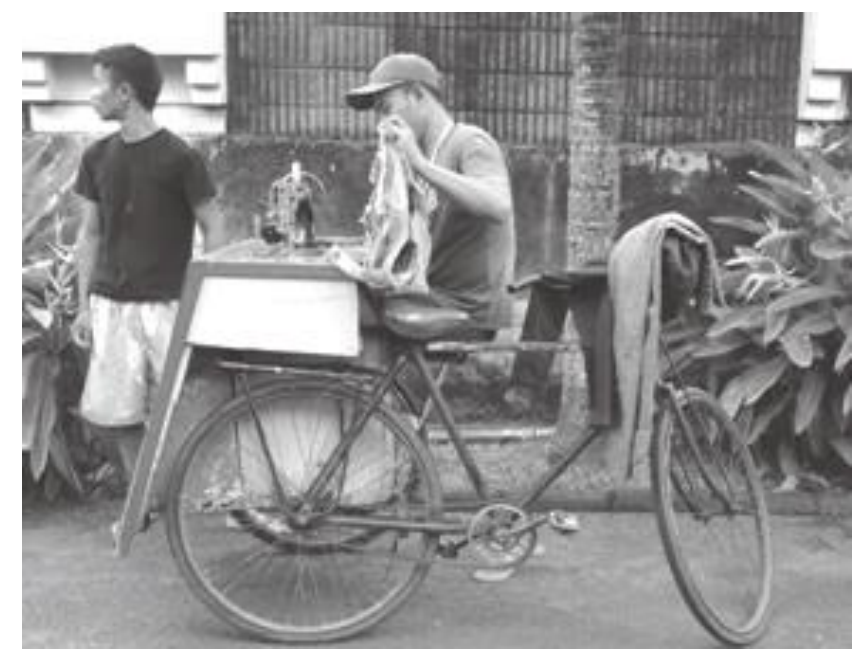

Gambar 8. Sarana Penjahit Keliling Model 1 dengan Bentuk Sepeda Utuh Sumber: Awang E.N.R, Maret 2014

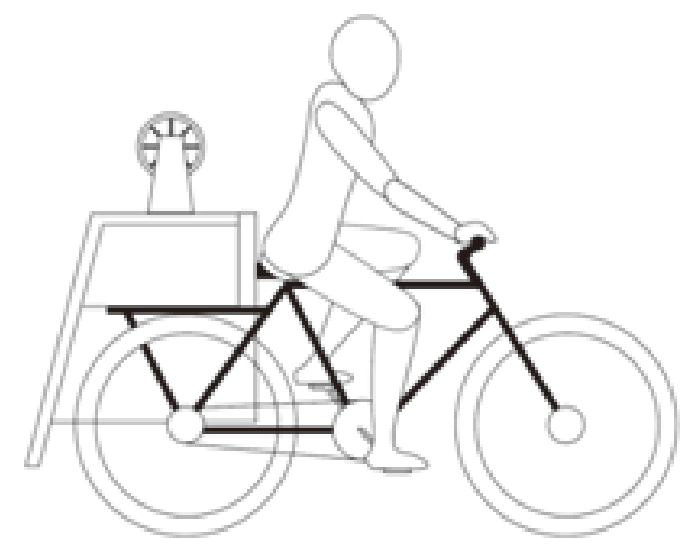

Gambar 9. Posisi Tubuh pada Aktivitas Mengayuh (Model 1) 


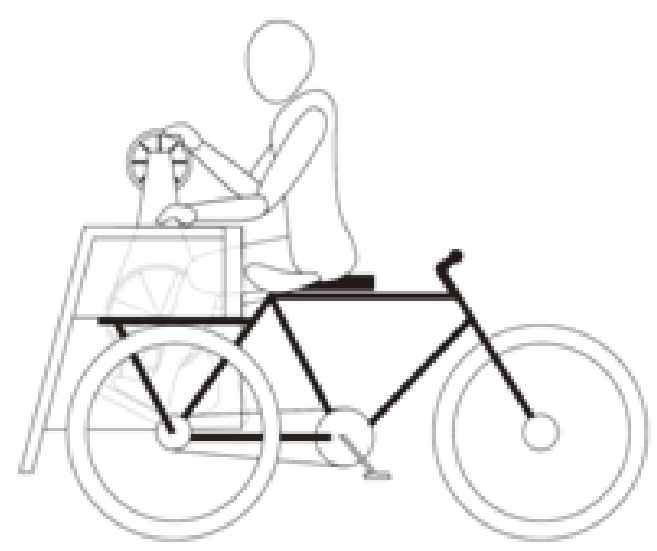

Gambar 10. Posisi Tubuh pada Aktivitas Menjahit (Model 1) Model 2 adalah sarana penjahit keliling dengan sistem las.

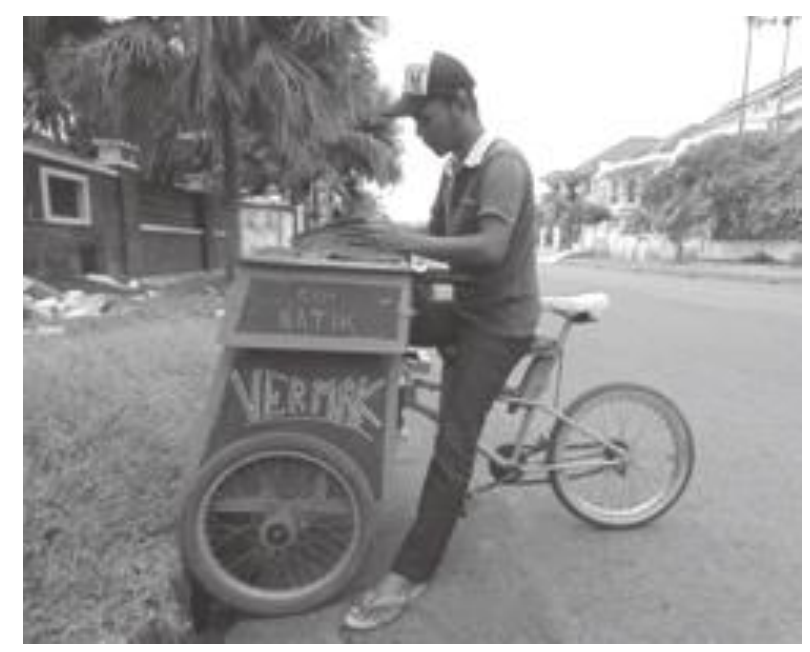

Gambar 11. Sarana Penjahit Keliling Model 2(a) dengan Sistem Las Sumber: Awang E.N.R, Desember 2013

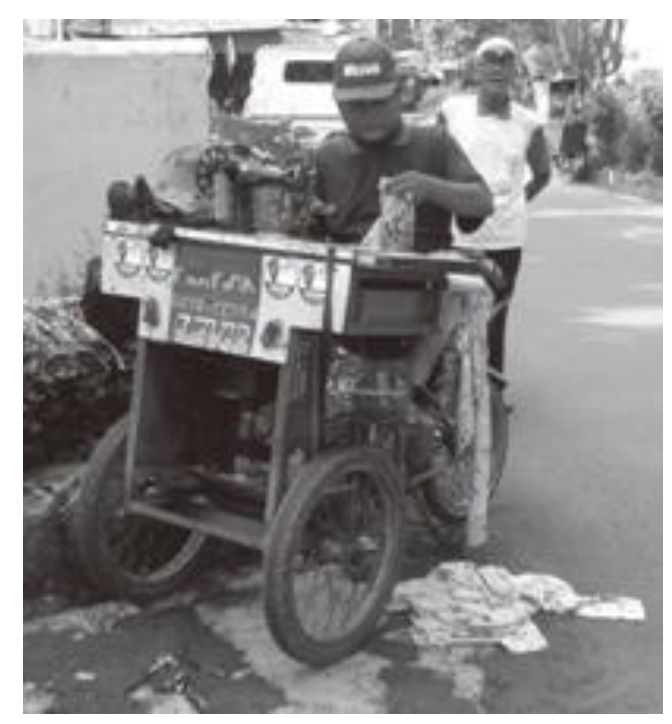

Gambar 12. Sarana Penjahit Keliling Model 2(b) dengan Sistem Las Sumber: Awang E.N.R, Juni 2014 
Sarana penjahit keliling ini dibuat di bengkel las, dengan modal Rp 1.200.000,- Rp 1.500.000.-. Bagian meja jahit dan kotak perlengkapan pada Model 2 terbuat dari material kayu, dengan dipadukan dengan bagian belakang sepeda. Model 2(b) memiliki bagian muka yang terbuka untuk mempermudah perawatan mesin jahit. Material yang digunakan juga material kayu yang digabungkan dengan bagian belakang sepeda. Lemari penyimpanan kotak kayu dan juga memanfaatkan bagian samping sarana penjahit keliling sebagai tempat menggantung berbagai perlengkapan yang dibawa.

Pada saat melakukan aktivitas mengayuh untuk sarana penjahit keliling
Model 2, posisi tubuh cenderung tegak (posisi tubuh mengendarai city bike). Tubuh bagian belakang dituntut tetap aktif untuk menjaga keseimbangan tubuh bagian atas. Posisi tangan menyesuaikan dengan posisi handle yang melebar di banding lebar bahu. Sedangkan posisi tubuh pada saat melakukan aktivitas menjahit, sebelah kaki berada pada pedal mesin jahit untuk menjalankan mesin jahit dan sebelah kaki lagi berada di luar kotak sarana dan menginjak lantai. Posisi kaki demikian dibutuhkan untuk lebih menjaga keseimbangan dan memberi kenyamanan tubuh penjahit tersebut.

Model 3 tidak berbeda jauh dengan Model 2, perbedaannya adalah pada bentuk

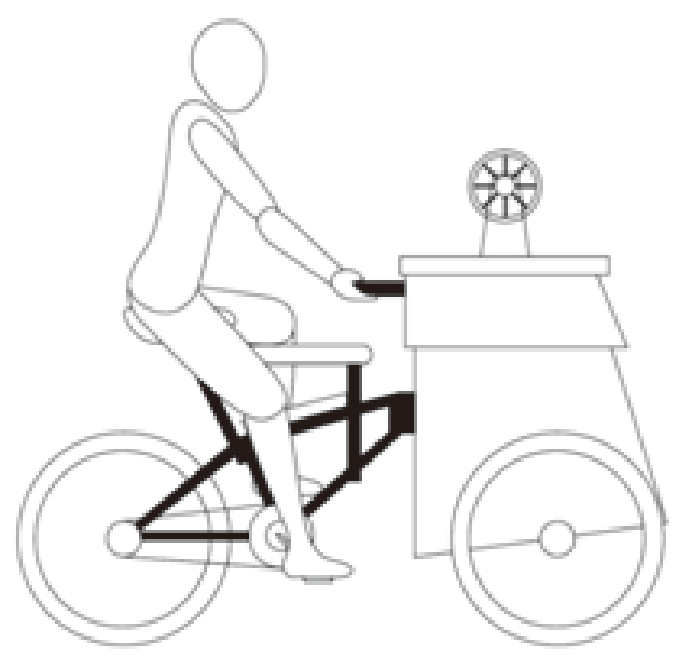

Gambar 13. Posisi Tubuh pada Aktivitas Mengayuh (Model 2)



Gambar 14. Posisi Tubuh pada Aktivitas Menjahit (Model 2) 


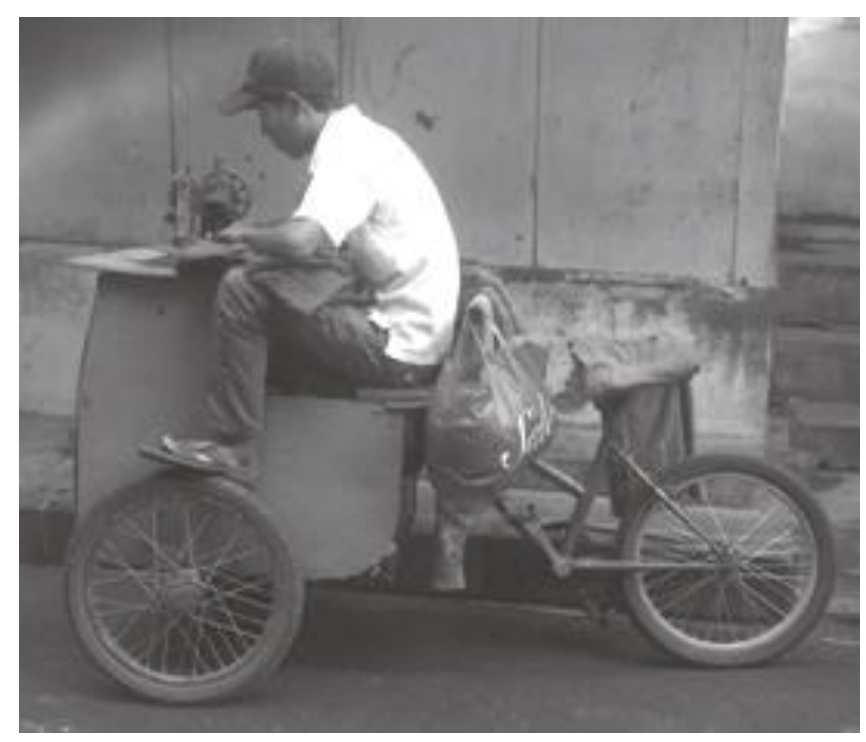

Gambar 15. Sarana Penjahit Keliling Model 3 dengan Kotak Besar Sumber: Awang E.N.R, Maret 2014

dan besar bagian kotak di muka. Model 3 keliling yang lebih baik. Sedangkan posisi memiliki bentuk kotak yang lebih besar, tubuh pada saat melakukan aktivitas menjahit, sehingga pengguna dapat duduk langsung sebelah kaki berada di dalam kotak mesin jahit menghadap ke mesin jahit dengan posisi dan sebelah kaki lagi berada di atas ban. tempat duduk yang menyatu dengan bagian Bentuk sarana penjahit keliling Model 3 yang kotak mesin jahit.

Posisi tubuh pada saat melakukan aktivitas mengayuh berada dalam posisi tegak, tetapi dengan jarak jangkauan tangan yang relatif lebih dekat dibandingkan dengan pada Model 2, karena posisi handle yang tidak terlalu jauh dari tubuh pengguna. Posisi ini memberi penguasaan terhadap sarana penjahit lebih lebar memberi ruang pada kaki dan tidak memungkinkan kaki untuk menginjak tanah sebagaimana pada Model 2. Posisi duduk pengguna berada pada bangku yang terdapat pada kotak sarana penjahit keliling tersebut, sehingga tubuh berada dalam posisi normal seperti menggunakan mesin jahit di meja yang statis.

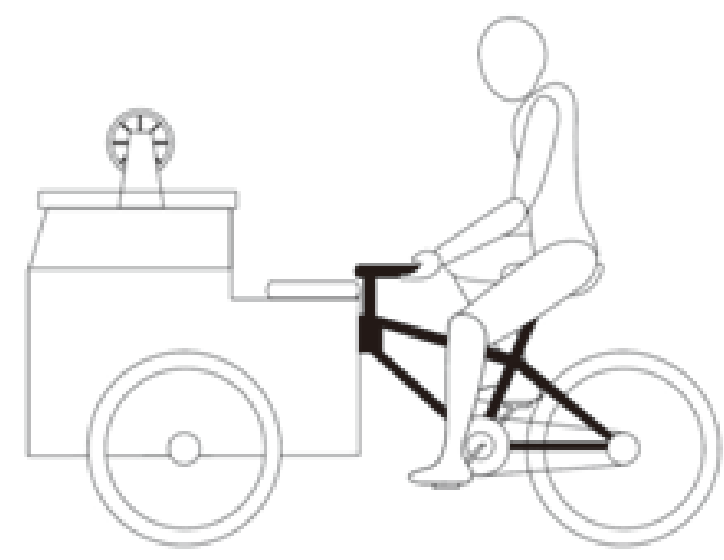

Gambar 16. Posisi Tubuh pada Aktivitas Mengayuh (Model 3) 


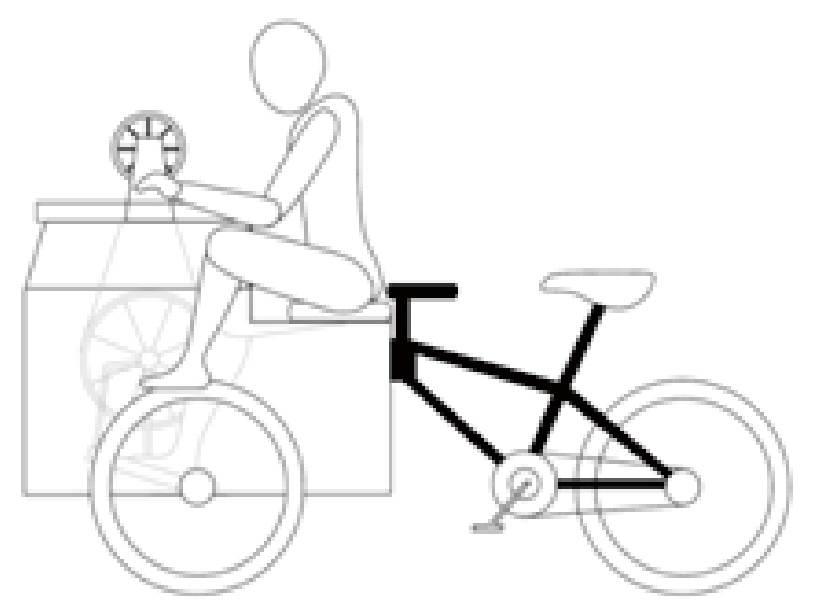

Gambar 17. Posisi Tubuh pada Aktivitas Menjahit (Model 3)

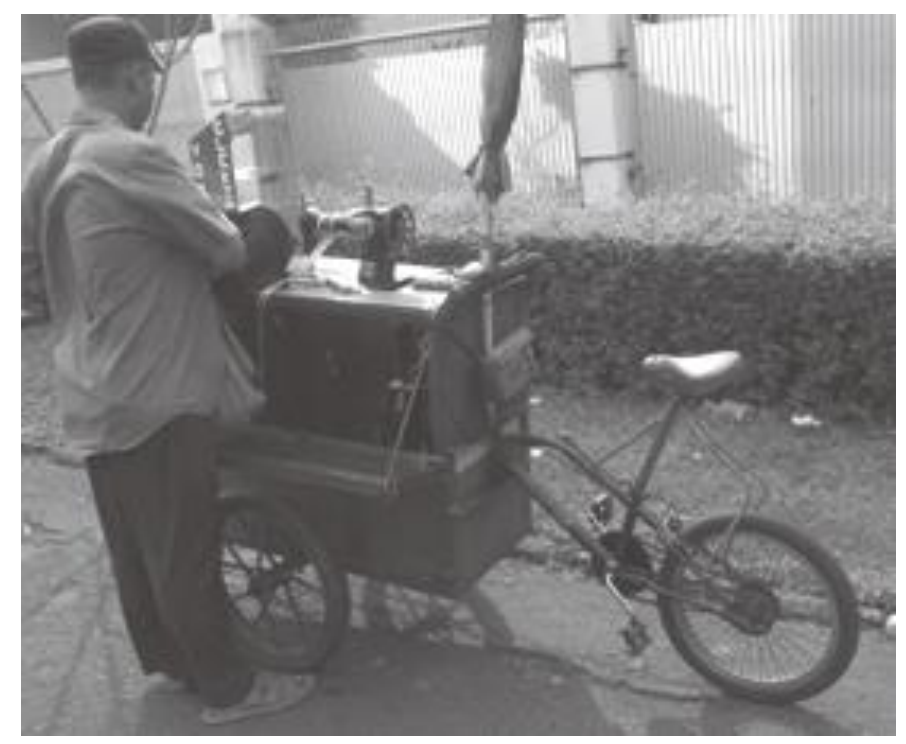

Gambar 18. Sarana Penjahit Keliling Model 4 dengan Mesin Menyamping Sumber: Awang E.N.R, Maret 2014

Model 4 adalah sarana penjahit keliling dengan mesin menyamping. Model $4 \mathrm{juga}$ memiliki bentuk penggabungan antara bagian kotak mesin jahit dengan bagian sepeda di sebelah belakang. Perbedaannya adalah posisi mesin jahit yang menyamping, sehingga pengguna tidak dalam posisi duduk di sadel ataupun menghadap muka, melainkan menempati posisi samping kotak sarana penjahit keliling tersebut. Model 4 bersifat lebih statis, karena pada saat me njahit pengguna tidak berada d iatas/mengendarai sarana penjahit keliling.
Pada model ini pengguna juga menambahkan payung untuk melindungi dari panas matahari dan hujan. Perbedaan hanya terletak pada bentuk handle yang membentang selebar kotak sarana penjahit keliing tersebut. Bentuk handle tersebut menyebabkan posisi bahu berada dalam posisi normal. Posisi kaki dan tubuh tegak sebagaimana posisi tubuh mengayuh city bike. 


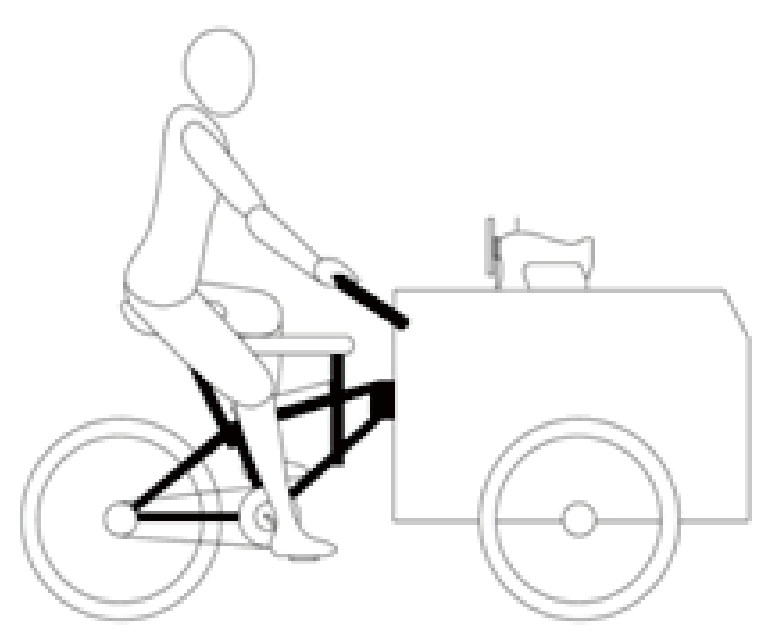

Gambar 19. Posisi Tubuh pada Aktivitas Mengayuh (Model 4)

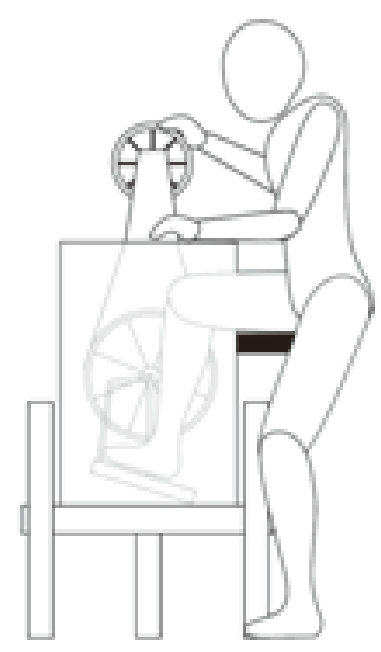

Gambar 20. Posisi Tubuh pada Aktivitas Menjahit (Model 4)

Bentuk sarana penjahit keliling Model 4 menyebabkan posisi tubuh pada saatmenjahit seperti berada pada meja jahit dengan bangku tinggi. Sebelah kaki berada di dalam kotak mesin jahit untuk mengayuh pedal mesin jahit, sedangkan sebelah kaki lagi berada di luar kotak dan menginjak tanah untuk menjaga keseimbangan.Model 5 adalah sarana penjahit keliling dari becak mini. Becak mini dimodifikasi dengan modal Rp 1.500.000,termasuk bentuk dasar becak mini tersebut. Material modifikasi adalah kayu untukbagian meja jahit dan plastik untuk bagian lemari penyimpanan di bagian samping sarana penjahit keliling. 


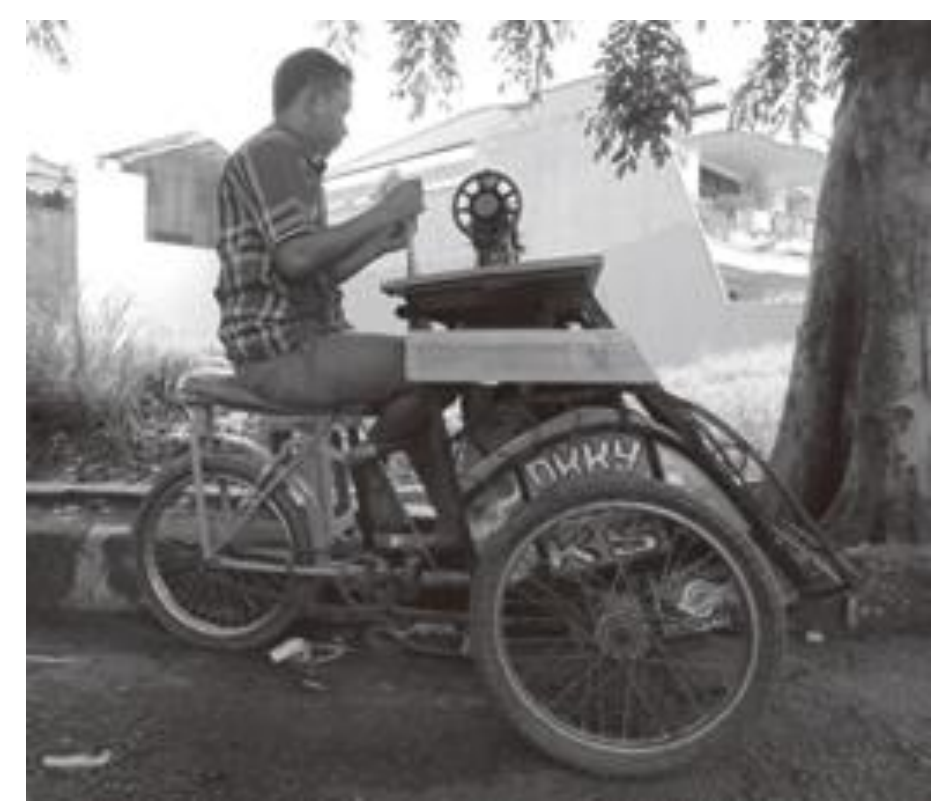

Gambar 21. Sarana Penjahit Keliling Model 5 dari Becak Mini Sumber: Awang E.N.R, Maret 2014

Pada sarana penjahit keliling Model 5 terdapat perbedaan beban keseimbangan tubuh yang dipengaruhi oleh bentuk dasar sarana yaitu becak. Pada saat melakukan aktivitas mengayuh, bobot masa tubuh bertumpu pada posisi duduk, dengan posisi tubuh yang cenderung tegak. Posisi tangan seperti juga pada Model 2, menyesuaikan dengan posisi handle yang lebih lebar daripada lebar bahu. Tinggi handle relatif lebih tinggi daripada tinggi handle sepeda, sehingga membutuhkan pengendalian yang lebih bertenaga. Untuk posisi tubuh pada saat melakukan aktivitas menjahit, posisi meja jahit yang tinggi, yang disebabkan oleh bentuk dasar becak menyebabkan jarak antara mata dengan bidang kerja relatif lebih dekat. Tubuh pengguna tidak perlu membungkuk pada saat bekerja, tetapi perlu diwaspadai timbulnya ketegangan otot pada bahu dan lengan. Posisi kaki sebelah berada di dalam rongga bawah becak, sedangkan sebelah kaki lagi mencari posisi tumpuan pada rangka ataupun $m$ enginjak tanah un tuk menjaga keseimbangan.

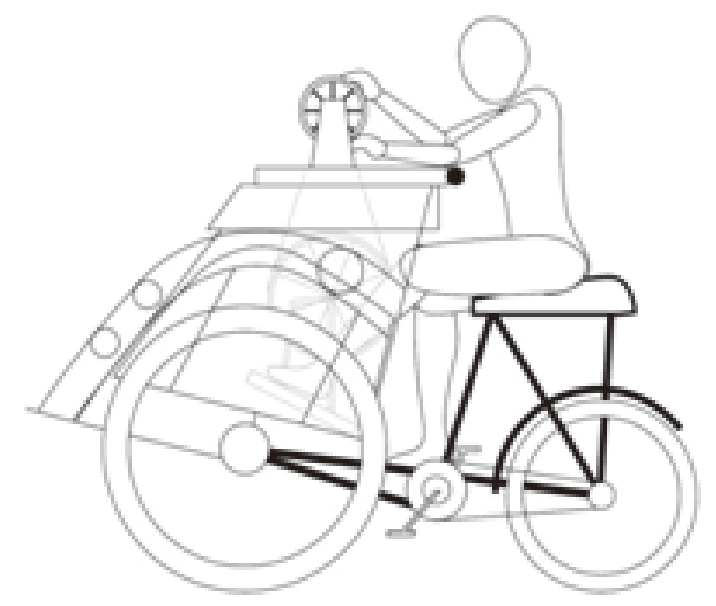

Gambar 22. Posisi Tubuh pada Aktivitas Menjahit (Model 5) 


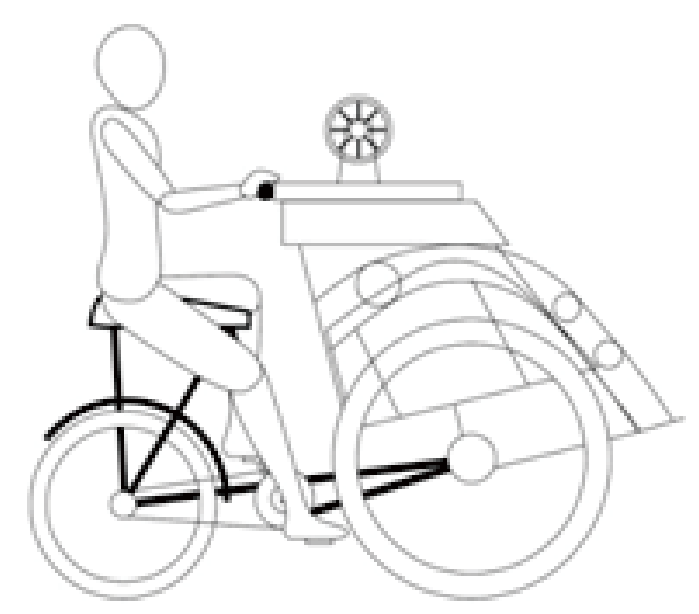

Gambar 23. Posisi Tubuh pada Aktivitas Mengayuh (Model 5)

Dari uraian di atas, berbagai ragam posisi tubuh pengguna pada saat berada dalam aktivitasnya baik aktivitas mengayuh maupun aktivitas menjahit mencari posisi yang memberi kenyamanan dalam beraktivitas. Posisi tubuh dalam beraktivitas mengayuh dan menjahit bukan merupakan posisi tubuh yang ideal. Meskipun demikian, posisi tubuh mengayuh yang paling mendekati ideal adalah pada pengguna sarana penjahit keliling Model 1, karena bentuk sepeda tetap utuh. Posisi tubuh ideal untuk menjahit sesuai dengan ketentuan ergonomi mesin jahit adalah posisi tubuh tegak dengan siku dan lutut membentuk sudut $90^{\circ}$ sehingga otot tidak ada yang tegang dan nyeri. Kedua kaki berada dalam posisi sama tinggi dan sejajar, dengan jarak yang normal selebar bahu. Tempat duduk dalam beraktivitas juga secara ideal perlu memiliki sandaran yang berada dalam posisi vertikal untuk menyangga punggung sehingga tulang belakang bagian pinggang dapat tersangga dengan baik. Pada sarana penjahit keliling Model 1, kedua kaki sudah dalam posisi sama tinggi dan sejajar, yaitu keduanya dapat berada di dalam kotak meja mesin jahit tersebut.Posisi tubuh akan menyesuaikan dengan posisi komponen sarana penjahit keliling dan bentuknya. Posisi tubuh juga mencari keseimbangan pada sendi-sendi geraknya sehingga tumpuan selalu berada di pusat tubuh. Proses pembiasaan dari pengguna yang beraktivitas secara rutin dalam jangka waktu yang lama untuk mencari nafkah menyebabkan gerak tubuh terbiasa dan mengalami penyesuaian. Otot dan anggota tubuh menjadi terbiasa dan pada akhirnya akan menghasilkan kenyamanan dan kondisi rileks pada saat beraktivitas.

\section{Simpulan}

Penjahit keliling di wilayah penelitian yaitu di wilayah perumahan Bintaro Jaya sektor 1 dan 2 menggunakan beberapa ragam bentuk dan desain sarana penjahit keliling yang disesuaikan dengan aktivitas dan kebutuhan pengguna primer dan sekunder. Adanya wilayah kerja yang tetap menyebabkan terciptanya keterikatan antara penjahit keliling dengan pelanggannya. Hal ini menyebabkan terbukanya peluang untuk perubahan dari yang tadinya berkeliling menjadi menetap. Dari yang mencari pelanggan karena kebutuhan menjadi dicari oleh pelanggan yang membutuhkan. Meskipun demikian, kedua situasi ini tetap membutuhkan sarana penjahit keliling yang dapat mendukung mobilitas dan memenuhi 
kebutuhan pengguna atas aktivitas menjahit yang menjadi aktivitas utama penjahit keliling.

Terdapat berbagai bentuk ragam desain sarana penjahit keliling di wilayah penelitian yaitu di Bintaro Jaya sektor 1 dan 2 . Berdasarkan pengamatan terdapat 5 (lima) model sarana penjahit keliling.
Keseluruhannya memiliki kelengkapan bagian meja jahit dan bagian penggerak yaitu memanfaatkan sepeda atau becak mini. Tempat penyimpanan alat dan bahan menjadi kelengkapan sarana penjahit keliling yang harus dipenuhi agar seluruh aktivitas pengguna dapat dilakukan di satu tempat, yaitu di sarana penjahit keliling tersebut.

Tabel 5. Ragam Bentuk dan Desain Sarana Penjahit Keliling

\begin{tabular}{|c|c|c|c|c|}
\hline Model & Bentuk Asal & $\begin{array}{l}\text { Sarana } \\
\text { Tambahan }\end{array}$ & $\begin{array}{l}\text { Kelengkapan } \\
\text { Sarana }\end{array}$ & Sisi Tubuh \\
\hline Model 1 & Sepeda onthel & $\begin{array}{l}\text { Kotak mesin } \\
\text { jahit pada } \\
\text { bagian } \\
\text { samping } \\
\text { sepeda }\end{array}$ & $\begin{array}{l}\text { - Mesin jahit } \\
\text { - Sarana } \\
\text { penyimpanan }\end{array}$ & $\begin{array}{l}\text { - Posisi tubuh } \\
\text { tegak } \\
\text { - Sebelah kaki di } \\
\text { luar kotak dan } \\
\text { menginjak } \\
\text { tanah }\end{array}$ \\
\hline $\begin{array}{l}\text { Model } \\
\text { 2(a) }\end{array}$ & City bike & $\begin{array}{l}\text { Kotak mesin } \\
\text { jahit pada } \\
\text { bagian depan } \\
\text { dengan sistem } \\
\text { las }\end{array}$ & $\begin{array}{l}\text { - Mesin jahit } \\
\text { - Sarana } \\
\text { penyimpanan } \\
\text { - Bel mekanik }\end{array}$ & $\begin{array}{l}\text { - Posisi tubuh } \\
\text { tegak } \\
\text { - Sebelah kaki di } \\
\text { luar kotak dan } \\
\text { menginjak } \\
\text { tanah }\end{array}$ \\
\hline $\begin{array}{l}\text { Model } \\
\text { 2(b) }\end{array}$ & City bike & $\begin{array}{l}\text { Kotak mesin } \\
\text { jahit pada } \\
\text { bagian depan } \\
\text { terbuka dengan } \\
\text { sistem las }\end{array}$ & $\begin{array}{l}\text { - Mesin jahit } \\
\text { - Sarana } \\
\text { penyimpanan } \\
\text { - Bel listrik }\end{array}$ & $\begin{array}{l}\text { - Posisi tubuh } \\
\text { tegak } \\
\text { - Sebelah kaki di } \\
\text { luar kotak dan } \\
\text { menginjak } \\
\text { tanah }\end{array}$ \\
\hline
\end{tabular}




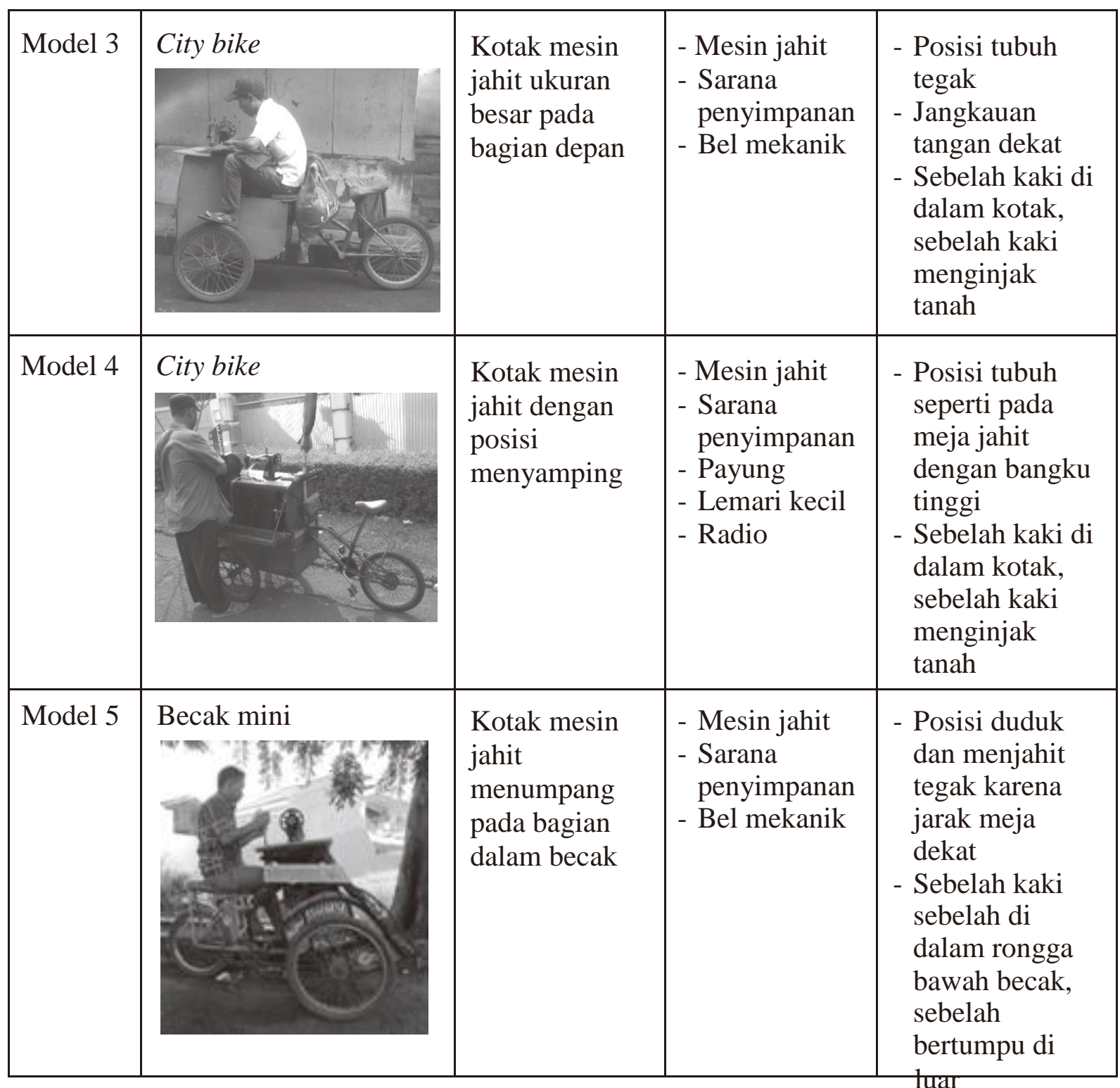

Sarana penjahit keliling memberi kemampuan untuk mobilitas di samping ruang untuk memenuhi kebutuhan pelanggan yang membutuhkan pekerjaan merombak /permakataupun pembuatan baju/celana dengan biaya terjangkau dan kemudahan aksesabilitas. Dalam melakukan aktivitasnya, posisi tubuh dan anggota badan pengguna disesuaikan dengan kebutuhan gerak, sambil tetap berada di atas tempat duduk (sadel) sarana penjahit keliling tersebut. Posisi kaki berada di atas pedal pada saat mengayuh sarana penjahit keliling untuk berpindah tempat, dan berada di atas injakan mesin jahit pada saat menggerakkan mesin sewaktu menjahit. Posisi tubuh penjahit keliling sebagai pengguna sarana penjahit keliling dalam melakukan aktivitas menjual jasanya, tidak selalu dalam posisi ideal yang memberi kenyamanan. Posisi tubuh kerap harus menyesuaikan dengan kondisi sarana penjahit keliling yang digunakan. Dalam aktivitas mengayuh dan aktivitas menjahit, otot-otot tubuh kemudian menyesuaikan dengan kondisi dan kebiasaan tubuh dalam bekerja. Posisi tubuh mencari kenyamanan maksimal yang mampu didapat, agar aktivitas dapat terus berlangsung dan pekerjaan dapat 
dilakukan oleh pengguna.

Hasil analisis pada penelitian ini dapat dijadikan titik tolak penelitian lanjutan. Bagi penelitian selanjutnya, penelitian dapat berfokus pada pengembangan rekomendasi desain dengan memperhatikan kebutuhan dan aspek ergonomi pengguna. Pengembangan desain sarana penjahit keliling dapat dikembangkan untuk lebih memudahkan pengguna dalam melakukan aktivitas dan memberi kenyamanan pengguna.

\section{Daftar Pustaka}

Balaram, S. (2011),Thinking Design, New Delhi: Sage Publication India Pvt Ltd.

Masri, Andri, (2010),Strategi Visual, Yogyakarta: Jalasutra.

Sachari, Agus, (2007), Sosiologi Desain, cetakan ke-2, Bandung: Penerbit ITB.

Islami, Mochamad Burhan, "Desain Rombong Penjual Makanan Kaki Lima S is tem Semi Prasmanan", http://digilib.its.ac.id/ITSUndergraduate-3100010041171/1464, diakses pada 19 Desember 2013.

Jenny, "7 Quick, Low-cost Fixes for Your Quilting Space (+sale)", http://blog. shopmartingale.com/quilting-sewing/7quick-quilting-room-design-ideas/, diakses pada 10 Februari 2014.

Patria- Bikes, “ Dutch Bicycle Sitting Position", http://www.patria.net/en/ ergonomics/dutch-bicycle-sittingposition/, diakses pada 18 Februari 2014. 